\title{
Livraisons d'histoire de l'architecture
}

La revue des jeunes chercheurs en histoire de l'architecture

\section{Laurence Marie}

\section{(2) OpenEdition}

\section{Journals}

Electronic version

URL: http://journals.openedition.org/labyrinthe/678

DOI: $10.4000 /$ labyrinthe. 678

ISSN: 1950-6031

\section{Publisher}

Hermann

\section{Printed version}

Date of publication: 14 January 2002

Number of pages: 147-148

\section{Electronic reference}

Laurence Marie, «Livraisons d'histoire de l'architecture », Labyrinthe [Online], 11 | 2002, Online since 15 April 2005, connection on 07 May 2019. URL : http://journals.openedition.org/labyrinthe/678; DOI : 10.4000/labyrinthe.678

This text was automatically generated on 7 May 2019.

Propriété intellectuelle 


\section{Livraisons d'histoire de l'architecture}

La revue des jeunes chercheurs en histoire de l'architecture

Laurence Marie 